\title{
Association of Nurses' Empathic Tendency and Attitudes to Ageism Toward Older Adults
}

\section{Hemşirelerin Empatik Eğilimi ile Yaşıllara Yönelik Ayrımcılık Tutumları Arasındaki İlişkisi}

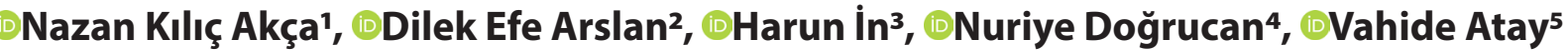 \\ 'İzmir Bakırçay University, Faculty of Health Sciences, İzmir, Turkey \\ 2Erciyes University, Halil Bayraktar Health Services Vocational College, Kayseri, Turkey \\ ${ }^{3}$ Health Sciences University Erzurum Regional Training and Research Hospital, Nursing, Erzurum, Turkey \\ ${ }^{4}$ Atatürk Vocational and Technical Anatolian High School, Health Teacher, Yozgat, Turkey \\ ${ }^{5}$ Ankara University Faculty of Medicine, Nursing, Ankara, Turkey
}

\begin{abstract}
Objective: This study aims to determine the correlation of nurses empathic tendency and ageism attitudes towards older adults
\end{abstract}

Material and Method: A descriptive and correlational with a convenience sample of 132 Turkey nurses was conducted in April-June 2017. Structured question form, Scale of Empathic Tendency and Fraboni Scale of Ageism (FSA) were applied to nurses.

Results: The regression model used in the study explains $16 \%$ of the factors affecting ageism in nurses. In this model, factors that remained negative attitude toward the elderly were female, obtaining information about the elderly from the media and willingness to care for the elderly $(p<0.05)$.

Conclusion: This study found that ageism and empathic tendencies of nurses were at moderate level. It is important to develop the empathic tendencies of nurses in preventing ageism. Accordingly, it can be suggested that nurses' knowledge on this subject should be improved with evidence-based practices.

Keywords: Ageism, empathy tendency, older adult, nursing care
Öz

Amaç: Bu çalışma, hemşirelerin empatik eğilim ve yaşı ayrımcılığı düzeyleri arasındaki ilişkiyi belirlemek amacıyla yapıldı.

Gereç ve Yöntem: Tanımlayıcı ve ilişkisel tipteki çalışma NisanHaziran 2017 tarihleri arasında 132 hemşire ile gerçekleştirildi. Hemşirelere yapılandırılmış soru formu, Empatik Eğilim Ölçeği ve Fraboni Ayrımclık Ölçeği uygulandı.

Bulgular: Çalışmada kullanılan regresyon modeli hemşirelerde yaşlı ayrımcılığını etkileyen faktörlerin \%16'sını açıkladı. Negatif yaşı ayrımclığı üzerine kadın olma, yaşlıya dair bilgileri medyadan elde etme ve yaşlı bakımında gönülü olmamanın etkili olduğu belirlendi.

Sonuç: Bu çalışmada, hemşirelerin yaşlı ayrımclığı ve empatik eğilim puanları orta düzeydeydi. Yaşlı ayrımlığının önlenmesinde hemşirelerin empatik eğilimlerinin geliştirilmesi önemlidir. Bu doğrultuda hemşirelerin bu konudaki bilgilerinin kanıta dayalı uygulamlarla geliştirilmesi önerilebilir.

Anahtar Sözcükler: Ayrımcılık, empatik eğilim, yaşlı, hemşirelik bakımı 


\section{INTRODUCTION}

Old age is a natural and inevitable process all people will experience. The elderly population in the world and in our country is increasing gradually with decreasing fertility, improved nutritional conditions, improvements in health services and the control over infectious diseases. ${ }^{[1]}$ According to the United Nations data, $12.3 \%$ of the world population is comprised of people who are 60 and over. ${ }^{[2]}$ In Turkey, While the proportion of the elderly people in the total population was $7.7 \%$ in 2013, it increased to $8.8 \%$ in 2018. In 2013, physical dependency rate of the elderly in Turkey was $11.3 \%$, while this figure has recently reached $12.9 \%{ }^{[3]}$ Therefore, to reduce the dependence of the elderly and to maintain their care, a wide service network is needed in all the institutions working in the field of health. ${ }^{[4]}$

Nurses have an important role in elderly care. Care is the use of nursing knowledge and skills to protect, develop, and promote health based on values such as empathy, compassion, reassurance, and help. Prejudices, negative feelings, beliefs and attitudes that nurses have while giving care to the elderly reduce their empathic approach and the quality of the care they give. One of the attitudes that can negatively affect care is ageism towards the elderly. Ageism is defined as prejudice or discrimination against or to the benefit of older adults because of their age. Ageism to older adults among nurses leads to inadequate allocation of health services and elder mistreatment. ${ }^{[5]}$ Nurses see the health problem the elderly experience as a natural process, yet they prefer to take care of young patients. Moreover, Higgins et al. study revealed that for nurses, giving care to the elderly is "a waste of time".[6] There are many factors such as social, cultural and individual values that affect ageism. Empathic tendency is predicted to be one of these factors. It is important to evaluate the effect of empathic tendency on attitudes towards the elderly in nurses. Empathic tendency in nurses is gaining importance in order to remove the attitudes that increase ageism and to increase the quality of care. ${ }^{[7,8]}$ The empathic tendency is defined asthe willingness to understand and help another person. ${ }^{[9,10]}$

Empathic tendency, which expresses the possibility of developing empathy, is an innate trait, developed by training and it renders the development of empathic attitude of an individual obligatory by creating the emotional dimension of empathy. This concept includes the ability to understand the emotions of the individuals with problems and to be influenced by their emotional experiences. People with high empathic tendencies show more helping behavior. ${ }^{[11]}$ Empathic sensitivity enables nurses to better understand the patients and to give them better quality care. The elderly feel valuable when they are given individualized care through empathy. ${ }^{[12-14]}$ The best way to understand and care for the elderly is to put yourself in the place of that person, which is best achieved by developing empathy. It is an important skill for nurses, educators, and all the people giving care. ${ }^{[15,16]}$ This study aims to determine the correlation of nurses empathic tendency and ageism attitudes towards older adults

\section{Research Questions}

1. What are the levels of empathic tendencies and ageism in clinic nurses?

2. Is there a relationship between empathic tendency and ageism attitudes towards older adults in clinic nurses?

3. What are the socio-demographic variables affecting the ageism?

\section{MATERIAL AND METHOD}

A descriptive and correlational study was conducted at a public hospital and a research and application in Turkey, from April to June 2017. At the began of the study power analysis ( $G^{*}$ Power (v3.1.7) was performed using in order to determine the sample size. The sample size was determined as 122 with 0.05 error margin and based on $95 \%$ confidence interval. The study was completed with 132 nurses (55 nurses from the research and application hospital and 67 nurses from the public hospital). At the end of the study power analysis that the average score willingness to care for the elderly with the average score Fraboni Scale of Ageism (FSA), the power of the study was found to be $95 \%$ at alpha $=0.05$. Nurses who working in pediatric, neonatal and maternity services were excluded.

\section{Data Collection}

The research data were collected using theThe Structured Question Form, Empathic Tendencies Scale and Fraboni Scale of Ageism. The data was collected through face to face interviews with the participants. The data were collected between 2:30 and 3:00 PM outside of treatment hours. Each interview lasted about 20-30 minutes.

The Structured Question Form: The structured question form(Includes a total of 17 questions) was prepared by the researchers by investigating the literature..$^{[9,10,12,14]}$

Empathic Tendencies Scale: The Likert type Empathic Tendencies Scale (ETS) was designed by Dokmen (1988) and the validity and reliability tests of the scale were conducted. ${ }^{[17]}$ ETS is a 5 point-Likert scale which includes 20 statements. The minimum and maximum scores to be obtained from the scale are 20 and 100 . As the score increases, empathic tendency also increases. The reliability coefficient of the ETS is $0.82 .{ }^{[17]} \mathrm{In}$ our study, cronbach's alpha was found to be 0.74 .

Fraboni Scale of Ageism: The scale was designed by Fraboni in 1990 and Kutlu, Kucuk \& Yildiz Findik (2012) conducted the reliability and validity studies of the scale in Turkey. ${ }^{[18,19]}$ The Turkish translation of the scale consists of 25 items. The highest score to be obtained from the scale is 100 , while the lowest score is 25. A higher score points to higher levels of ageism. The scale includes three sub-dimensions: Prejudice, Avoidance and Discrimination. The Croanbach's alpha of the original version of the scale was found to be 0.83 , while that of the Turkish version is $0.84{ }^{[18,19]}$ In our study, cronbach's alpha was found to be 0.77 . 


\section{Ethical declarations}

Approval for the conduct of the study was obtained from the ethics committee of Bozok University Faculty of Medicine NonInvasive Trial Ethics Committee (Decision Number:2017/12/2). Institution permission was obtained. Written informed consent was obtained from the participants before data collection. The study was conducted in compliance with ethical standards.

\section{Statistical Analysis}

SPSS 15.0 (Statistical Package for Social Sciences) was used to analyze the data. The Kolmogorov-Smirnov test and ShapiroWilk test were used to assess normally distributed data. Research findings were obtained by percentage, frequency, arithmetic mean, standard deviation and student's t-test. The multiple regression analysis were used. In group comparisons, statistical significance was assessed at $95 \%$ confidence interval and at $\mathrm{p}<0.05$.

\section{RESULTS}

This study $59.8 \%$ of the nurses were in the $18-35$ years group and mean $32.7 \pm 8.3$ years; $78.0 \%$ of them were female; $18.9 \%$ worked in the internal medicine clinic. $15.2 \%$ of the participants stated that they acquired the most recent information about the elderly from the media. $44.7 \%$ of the nurses said they received training on establishing communication with the elderly. Furthermore, $65.6 \%$ of the nurses in our study stated that they did not want to take care of the elderly in the clinic (Table 1).

Average FSA score of the nurses is $58.9 \pm 8.3$ (min:31-max: 80 ), pointing to a moderate level. The scores for the subdimensions of FSA from the highest to the lowest are $29.1 \pm 4.8$ (min: 11- max: 42) for prejudice, 17.9 \pm 3.4 (min: 9- max: 28) for avoidance, and 10.9 \pm 2.4 (min: 5- max: 18) for discrimination. ETS total score average of the nurses is $70.9 \pm 9.1$ ( $\mathrm{min}: 50$ max: 91) (Table 2).

It was found that total FSA scores and prejudice scores of the female nurses were higher compared to the scores of the male nurses. 36+ age group had higher prejudice scores compared to the $18-35$ age group $(p<0.05)$. It was found that particularly the nurses who used media to acquire information about the elderly had statistically higher FSA, avoidance and discrimination scores and this way of reaching information had an effect on ageism level. Prejudice, avoidance, and FSA scores of the nurses who did not want to care for the elderly in the clinic were statistically significantly higher compared to those who wanted to work with the elderly $(p<0.01)$ (Table 3 ).

Multiple regression was conducted to examine the contribution of significant gender, obtaining information about the elderly from the media, willingness to care for the elderly and empathic tendency. The final model was significant and explained $16 \%$ of the variance in ageism. In this model, factors that remained the negative attitude toward the elderly were gender, obtaining information about the elderly from the media, willingness to care for the elderly $(p<0.05)$ and empathic tendency ( $p>0.05)$ (Tablo 4).

\begin{tabular}{|c|c|c|}
\hline Characteristics & $\mathbf{n}$ & $\%$ \\
\hline Years $(\mathrm{X}+\mathrm{SD})$ & \multicolumn{2}{|c|}{$32.7 \pm 8.3$} \\
\hline $18-35$ years & 79 & 59.8 \\
\hline $36+$ years & 53 & 40.2 \\
\hline \multicolumn{3}{|l|}{ Gender } \\
\hline Female & 103 & 78.0 \\
\hline Male & 29 & 22.0 \\
\hline \multicolumn{3}{|l|}{ Family type } \\
\hline Nuclear & 119 & 90.2 \\
\hline Extended & 13 & 9.8 \\
\hline \multicolumn{3}{|l|}{ Place of residence } \\
\hline City & 85 & 64.4 \\
\hline Town & 47 & 35.6 \\
\hline \multicolumn{3}{|l|}{ Clinic } \\
\hline Internal medicine & 25 & 18.9 \\
\hline Emergency & 23 & 17.4 \\
\hline Intensive care & 21 & 15.9 \\
\hline Polyclinic & 18 & 13.6 \\
\hline Surgical service & 21 & 15.9 \\
\hline Operating room & 15 & 11.4 \\
\hline Dialysis center & 9 & 6.8 \\
\hline Working time in the profession $(\mathrm{X}+\mathrm{SD})$ & \multicolumn{2}{|c|}{$11.2 \pm 8.5$ years } \\
\hline \multicolumn{3}{|c|}{ Receiving care from the elderly during childhood } \\
\hline Yes & 20 & 15.2 \\
\hline No & 112 & 84.8 \\
\hline \multicolumn{3}{|l|}{ Taking care of an elderly } \\
\hline Yes & 65 & 59.1 \\
\hline No & 67 & 40.9 \\
\hline \multicolumn{3}{|c|}{ Obtaining information about the elderly from the media } \\
\hline Yes & 20 & 15.2 \\
\hline No & 112 & 84.8 \\
\hline \multicolumn{3}{|c|}{ Receiving training on communicating with the elderly } \\
\hline Yes & 59 & 44.7 \\
\hline No & 73 & 55.3 \\
\hline \multicolumn{3}{|l|}{ Willingness to care for the elderly } \\
\hline Yes & 45 & 34.4 \\
\hline No & 87 & 65.6 \\
\hline \multicolumn{3}{|c|}{ Reasons behind not wanting to take care of the elderly $(n=45)^{*}$} \\
\hline Physically and mentally tiring & 31 & 23.7 \\
\hline Hard to communicate with the elderly & 29 & 22.1 \\
\hline Leading to burnout & 27 & 20.6 \\
\hline Elderly's being grumpy and stubborn & 14 & 10.7 \\
\hline
\end{tabular}

$\mathrm{X}$ : Aritmethic mean, SD: Standart deviation * More than one answer was given.

Table 2. Distribution of ETS and FSA score averages of nurses $(n=132)$

\begin{tabular}{lc}
\hline Scales & $\mathbf{X} \pm \mathbf{S D}$ (Min-Max) \\
\hline ETS score & $70.9 \pm 9.1(50-91)$ \\
Low (below 63) & $17.2 \%$ \\
Average (63-72) & $41.4 \%$ \\
High (73 and $\uparrow$ ) & $41.4 \%$ \\
FSA score & $58.9 \pm 8.3(31-80)$ \\
Prejudice & $29.1 \pm 4.8(11-42)$ \\
Avoidance & $17.9 \pm 3.4(9-28)$ \\
Discrimination & $10.9 \pm 2.4(5-18)$ \\
\hline$X:$ Aritmethic mean, SD: Standart deviation FSA: Fraboni Scale of Ageism \\
ETS: Empathic Tendencies Scale
\end{tabular}




\begin{tabular}{|c|c|c|c|c|}
\hline Characteristics & $\begin{array}{c}\text { Prejudice } \\
\text { X } \pm \text { SD }\end{array}$ & $\begin{array}{c}\text { Avoidance } \\
\mathrm{X} \pm \text { SD }\end{array}$ & $\underset{X \pm S D}{\text { Discrimination }}$ & $\begin{array}{l}\text { FSA } \\
\mathrm{X} \pm \text { SD }\end{array}$ \\
\hline \multicolumn{5}{|l|}{ Age } \\
\hline $18-35$ & $28.4 \pm 4.2$ & $18.1 \pm 3.2$ & $10.8 \pm 2.3$ & $57.3 \pm 7.3$ \\
\hline 36 and above & $30.2 \pm 5.5$ & $17.7 \pm 3.6$ & $11.1 \pm 2.5$ & $58.9 \pm 9.6$ \\
\hline $\mathrm{p}$ & 0.041 & 0.571 & 0.582 & 0.268 \\
\hline \multicolumn{5}{|c|}{ Place of Residence } \\
\hline City & $27.1 \pm 3.8$ & $17.7 \pm 3.4$ & $11.1 \pm 2.5$ & $58.4 \pm 5.5$ \\
\hline Town & $28.7 \pm 4.4$ & $18.4 \pm 3.7$ & $10.8 \pm 2.7$ & $60.2 \pm 8.7$ \\
\hline $\mathrm{p}$ & 0.128 & 0.594 & 0.811 & 0.374 \\
\hline \multicolumn{5}{|l|}{ Gender } \\
\hline Female & $29.6 \pm 4.4$ & $18.2 \pm 3.3$ & $10.1 \pm 2.4$ & $58.9 \pm 7.9$ \\
\hline Male & $27.1 \pm 5.6$ & $17.0 \pm 3.5$ & $11.0 \pm 2.4$ & $54.6 \pm 8.9$ \\
\hline $\mathrm{p}$ & 0.013 & 0.110 & 0.170 & 0.013 \\
\hline \multicolumn{5}{|c|}{ Obtaining information about the elderly from the media } \\
\hline Yes & $30.6 \pm 4.7$ & $19.4 \pm 2.3$ & $12.1 \pm 2.9$ & $62.1 \pm 86.6$ \\
\hline No & $28.8 \pm 4.8$ & $17.6 \pm 3.5$ & $10.7 \pm 2.3$ & $57.2 \pm 8.4$ \\
\hline $\mathrm{p}$ & 0.119 & 0.031 & 0.026 & 0.015 \\
\hline \multicolumn{5}{|c|}{ Receiving training on communicating with the elderly } \\
\hline Yes & $29.1 \pm 4.4$ & $17.8 \pm 3.5$ & $11.1 \pm 2.5$ & $58.0 \pm 7.5$ \\
\hline No & $29.1 \pm 5.2$ & $18.0 \pm 3.3$ & $10.8 \pm 2.3$ & $57.9 \pm 8.9$ \\
\hline $\mathrm{p}$ & 0.990 & 0.752 & 0.572 & 0.977 \\
\hline \multicolumn{5}{|c|}{ Willingness to care for the elderly } \\
\hline Yes & $27.4 \pm 5.2$ & $16.6 \pm 3.5$ & $10.5 \pm 2.5$ & $54.6 \pm 8.6$ \\
\hline No & $29.9 \pm 4.4$ & $18.5 \pm 3.2$ & $11.1 \pm 2.3$ & $59.6 \pm 7.6$ \\
\hline$p$ & 0.005 & 0.003 & 0.175 & 0.001 \\
\hline
\end{tabular}

Table 4. The effect of various factors on the FSA score of nurses $(n=132)$
\begin{tabular}{lccc} 
Independent variables & B & SE & $\boldsymbol{\beta}$ \\
\hline Constant & 67.280 & 8.119 & \\
Gender & -4.763 & 1.660 & $-.241^{*}$ \\
Obtaining information about & -5.441 & 1.908 & $-.239^{*}$ \\
the elderly from the media & 4.231 & 1.420 & $.250^{*}$ \\
Willingness to care for the elderly & -.007 & .076 & .007 \\
Empathic tendency & & & \\
\hline${ }^{*} \mathrm{p}<0.05$ R: 0.42 R2: 0.17 Adjusted R2: 0.16 F:8.177 $\mathrm{p}<0.001$ & & \\
\hline
\end{tabular}

\section{DISCUSSION}

Health professionals also have prejudice about aging, which may lead to discriminatory behavior. ${ }^{[15,20-22]}$ The negative prejudice, values, beliefs and attitudes of health professionals, especially the nurses responsible for care, against the elderly influence the quality of the care given to the elderly. ${ }^{[23-27]}$ It was also found that the sub-dimensions of the FSA ageism scale (prejudice, avoidance and discrimination)were at moderate levels. Previous studies in the literature revealed similar results. ${ }^{[7,26,27]}$ The study suggest that the adoption of the belief that the elderly should be respected depending on the cultural significance of aging in the Turkish society and the region where the study was conducted is effective in reducing discrimination.
Regression analyses showed that this model accounted for $16 \%$ of the variance in ageism. In this study, more than half of the nurses stated that they did not want to take care of the elderly in the clinic. The main reasons were that taking care of the elderly was perceived as being physically and mentally exhausting, that establishing interaction with the elderly is difficult, and that taking care of the elderly leads to burnout. It was found that the nurses who did not want to take care of the elderly in the clinic exhibited prejudice and avoidancetoward the elderly and were more ageist. A systematic review of 25 studies conducted that all over the world, the positive attitude toward the elderly has been decreasing since 2000 , while the negative attitude has been gradually increasing. ${ }^{[28]}$

Media presents aging as a negative and undesirable process. ${ }^{[29,30]}$ One significant finding of our study is that avoidance and discrimination scores of the nurses who recently acquired some information about the elderly from the mediaare higher and they were found to be more ageist. Thus, it is necessary for countries to increase the sensitivity of the society by taking measures against ageism in media.

Our study further revealed that female nurses over 36 had higher scores of prejudice and ageism. This may be attributed to the fact that due to the cultural norms in Turkey, female nurses take care of the elderly at home as well as at their workplace, and the burden on their shoulders increase with the advance of the age of the elderly; thus their prejudice and ageism against the elderly increase. ${ }^{[24]}$

Empathic tendency is the determinant of the level of help individuals. Our study revealed that the nurses had moderate level of empathic tendency. In addition, this study revealed that as empathic tendency levels of nurses decrease, they show more avoidance of the elderly. This finding points to the fact that as the empathic tendencies of nurses are reinforced, avoidance from the elderly decreases and consequently, the quality of the care can be increased. ${ }^{[2,31]}$ Because, empathictendency is a vital element in all activities of nursing and is thebasic element of human-oriented holistic and humanistic nursing care. ${ }^{[32,33]}$

\section{CONCLUSION}

This study found that ageism and empathic tendencies of nurses were at moderate level. As health professionals should be aware of their empathic tendencies and improve their empathic skills through professional training and practice.

\section{Limitations}

The study has some limitations. The sample of the study consisted of the clinic nurses working in internal and surgery services. Therefore, the fact that the results of the study can not be generalized to clinic nurses is one of the limitations of the study. 


\section{ETHICAL DECLARATIONS}

Ethics Committee Approval: Approval for the conduct of the study was obtained from the ethics committee of the faculty (Approval No:2017/12/2).

Informed Consent: Because the study was designed retrospectively, no written informed consent form was obtained from patients.

Referee Evaluation Process: Externally peer-reviewed.

Conflict of Interest Statement: The author(s) declared no potential conflicts of interest with respect to the research, authorship, and/or publication of this article.

Financial Disclosure: The authors declared that this study has received no financial support.

Author Contributions: All of the authors declare that they have all participated in the design, execution, and analysis of the paper, and that they have approved the final version.

\section{REFERENCES}

1. Bowen CE, Skirbekk V. Old age expectations are related to how long people want to live. Ageing Society 2017;37(9):1898-923.

2. World Population Ageing (2019) https://www.un.org/en/ development/desa/population/publications/pdf/ageing/ WorldPopulationAgeing2019-Highlights.pdf

3. Turkish Statistical Institute (TUIK). Population Projections 2018-2080. Ankara: Turkey. 2018. https://hsgm.saglik.gov.tr/depo/birimler/kronikhastaliklar-engelli-db/hastaliklar/Yasli_Sagligi/raporlar_istatistikler/ TUIK_Yasli_Istatistik_2018.pdf

4. Korkmaz Aslan G, Kulakçı Altıntaş H, Özen Çınar İ, Veren F. Attitudes to ageing and their relationship with quality of life in older adults in Turkey. Psychogeriatrics 2019;19(2):157-64.

5. Levy SR, Macdonald JL. Progress on understanding ageism. Journal of Social Issues 2016;72(1):5-25.

6. Higgins I, Riet DVP, Slater L, Peek C. The negative attitudes of nurses towards older patients in the acute hospital setting:A qualitative descriptive study. Contemp Nurse 2007;26(2):225-37.

7. Bakan $A B$, Karadag Arli S, Varol E. Identification of nursing students' attitudes toward older people, Contemp Nurse 2018;54(3):284-92.

8. Kim J, Lee JE. Social Support and health-related quality of life among elderly individuals living alone in South Korea. J Nurs Res 2018;26(5):31623.

9. Akgun Sahin Z, Kardaş ÖzdemirF. (2015). Determination of communication and empathy skill levels of nurses. J Acad Res Nurs 2015;1(1):1-7.

10. Moghaddasian S, Dizaji SL, Mohtar M. Nurses empathy and familiy needs in the intensive care units. J Caring Sc 2013;2(3):197-201.

11. Dokmen, Ü. Communication conflicts and empathy in art and everyday life. Sistem Yayıncılık, İstanbul, 2009.

12. Alhadidi MM, Abdalrahim MS, Al-Hussami M. Nurses' caring and empathy in Jordanian psychiatric hospitals:A national survey. Int J Ment Health Nurs 2016; 25(4), 337-45.

13. Guven Ozdemir N, Sendir M. The relationship between nurses' empathic tendencies, empathic skills, and individualized care perceptions. Perspect Psychiatr Care. 2020; 56:732-7.

14. Suhonen R, Valimaki M, Leino-Kilpi HA. Rreview of outcomes of individualised nursing interventions on adult patients. J Clin Nurs 2018;17(7):843-60.

15. Bulut E, Cilingir D. Ageism and reflections of nursing care. TAF Prevent Med Bull 2016;15(5):446-9.
16. Avci D, Alp Yilmaz F. Association between Turkish clinical nurses perceptions of individualized care and empathic tendencies. Perspect Psychiatr Care 2021;57: 524-30.

17.Dokmen Ü. Empatinin yeni bir modele dayanarak ölçülmesi ve psikodrama ile geliştirilmesi. Ankara Üniversitesi Eğitim Bilimleri Fakültesi Derg 1988;21, 1-2.

18. Fraboni Saltstone R, Hughes S. The Fraboni Scale of Ageism (FSA):An attempt at a more precise measure of ageism. Can J Aging 1990; 9(1):5666.

19. Kutlu Y, Kucuk L, Yildiz Findik U. Psychometric properties of the Turkish version of the Fraboni Scale of Ageism. Nurs Health Sc 2012;14(4):464-71.

20. Turgay AS, Şahin S, Şenuzun Aykar F, et al. Attitudes of Turkish nursing students toward elderly people. Eur Geriatr Med 2015;6(3):267-70.

21. Kılıc NP. Individual ageism in health. E kurgu-Anadolu Üniversitesi İletişim Bilimleri Fakültesi Uluslar Arası Hakemli Derg 2017;25(3):53-77.

22. Ouchida Karin M, Lachs Mark S. (2015). Not for doctors only:ageism in healthcare. J Am Soc Aging 2015;39(3):46-57.

23. Senturk S, Güzel A, Ergün G, Çetinkaya A. Determination of the knowledge and awareness of nursing students about elder neglect and abuse:The case in Turkey. Perspect Psychiatr Care 2020:1-8.

24. Ugurlu Z, Kav S, Karahan A, Akgun Çıtak E. Correlates of ageism among health care professionals working with older adults. J Transcult Nurs 2019;30(3):303-12.

25. Rababa, M, Hammouri, AM, Hweidi, IM, Ellis, JL. Association of nurses' level of knowledge and attitudes to ageism toward older adults: Crosssectional study. Nurs Health Sci. 2020;22:593-601.

26. Darling R, Sendir M, Atav S, Buyukyilmaz F. Undergraduate nursing students and the elderly: An assessment of attitudes in a Turkish university. Gerontol Geriatr Educ. 2018;39(3):283-94. .

27. Lan X, Chen Q, Yi B. Attitude of nurses toward the care of older adults in China. J Transcult Nurs 2019;30(6):597-602.

28. Liu Y, Norman IJ, While AE. Nurses' attitudes towards older people:a systematic review. Int J Nurs Stud 2013;50:1271-82.

29. Kroon AC, Trilling D, Van Selm M, Vliegenthart R. Biased media? How news content influences age discrimination claims. Eur J ageing 2019;16(1):10919.

30. Demir I. The Reproduction of Ageism in Humor Magazines. Senex:Yaşlılık Çalışmaları Derg 2017;1(1): 57-75.

31. Schmidt BJ, McArthur EC. Professional nursing values:A concept analysis. In Nursing Forum 2018;53(1):69-75.

32. Laganá L, Gavrilova L, Carter DB, Ainsworth AT. A Randomized Controlled Study on the Effects of a Documentary on Students' Empathy and Attitudes towards Older Adults. Psychol Cogn Sci. 2017;3(3):79-88.

33. Kuçukguclu Ö, Söylemez BA. Elderly people's views, experiences and expectations about the required and desired competences of social and health care professionals working with elderly people. Dokuz Eylül University Electronic Journal of Nursing Faculty 2017;10(4):260-6. 